\title{
PART 4. ACTIVITY OF THE HUNGARIAN AGENTS IN CARPATHIAN UKRAINE
}

Archival documents clearly show that the historical fate of Transcarpathia during the 1920-30's was constantly in the field of view of the government of Ukraine, but no less attention was paid to this problem by Hungary and other neighboring states. Throughout the interwar period on the territory of our region and beyond its borders there was an active Hungarian irredent, who sought to return the ancient Ukrainian land to the bosom of the Holy Stephen's Crown. It is known that according to the Saint-Germain Peace Treaty, Transcarpathia was included in Czechoslovakia, which clearly did not suit the Hungarian government and political parties of the country. They sought at any cost to include Transcarpathia in Hungary. On August 5, 1919 the Ugro-Rus' Party of Hungary adopted a memorandum to the Entente regarding this issue. In it we can read next: "...The Ruthenian question could best be solved... as for a thousand years the Ruthenians were always ready to come to the Hungarians, and now they want to fulfill their will the same way" ${ }^{300}$. The Memorandum was signed by M. Kutkafalvi-Kutka, I. Prodan, V. Balog, J. Illesh-Ilyashevych, I. Danylovych, S. Dzupan, all about one hundred people. This memorandum, so as several others, did not affect the decision of the Paris Conference, but from that time onwards the Hungarian agents launched intensive activities in Transcarpathia. The head of the Civic Office of Subcarpathian Rus' I. Breich on January 10, 1920, informed the Civic Office in Mukachevo that "the situation in Beregovo, as a result of continuous Hungarian-monarchist agitation, makes the use of various intimidation measures impossible" ${ }^{301}$.

On March 17, 1920, the "Kashshai Munchash" newspaper posted on its front pages a report of increased terror in the cities of

300 ДАЗО. Ф. 63. Оп. 1. Спр. 18. Арк. 1-4.

301 ДАЗО. Ф. 14/43 с. Оп. 1. Спр. 15. Арк. 84. 
Mukachevo and Beregovo. It stated that the policy of terror was supported by the Hungarian Christian-Socialist Party, which was active primarily in Mukachevo, Beregovo and Uzhgorod ${ }^{302}$. This party "sympathizes with Regent Horthy and is well aware that it represents the Hungarian irredent" ${ }^{303}$. Beginning in 1920, the Hungarian agency started to establish on the territory of Transcarpathia its own organizations, subversive terrorist units, which were to destabilize the internal political situation in Czechoslovakia as a whole. On June 17, 1920 the chief of the police department of the Civic Office of Subcarpathian Rus' issued an order requiring to investigate and take decisive action against the establishment of Hungarian propaganda centers in Transcarpathia. The document stated that "in Slovakia and in Subcarpathian Rus', namely in the Sharysh and Zemplin counties, a special anti-state military organization is created by the special Hungarian military command, which is called "Command in Upper Hungary", and which has a residence in Miskolc and is subordinated to the propaganda center in Budapest" ${ }^{\prime 304}$. According to archival sources, similar organizations existed in other counties. The military organization of the Sharysh, Zemplin, and Abauj counties was headed by Colonel Linder. Weapons for these organizations were sent from Poland and Hungary in empty oil tanks. It has been suggested that all anti-Czech propaganda is headed by the Slovak Bulisa and Professor Davski in Warsaw $^{305}$.

It is ineresting that the activities of the pro-Hungarian "fifth column" in the region were well known in Slovakia, and its figures repeatedly informed the Civic Office of Subcarpathian Rus' about this. Here is the information that came from Bratislava on October 7 , 1920: “...The administration in Subcarpathian Rus' is made up of agents of the Hungarian irredent. The reason for this is that officials of the Hungarian way of thinking, who carry out the Hungarian propaganda and sabotage activity, who wait for Horthy, are not eliminated anywhere, which undoubtedly had to be done in the

\footnotetext{
302 ДАЗО. Ф. 14. Оп. 1. Спр. 17. Арк. 84.

303 ДАЗО. Ф. 63. Оп. 1. Спр. 1. Арк. 14.

304 ДАЗО. Ф. 29. Оп. 3. Спр. 36. Арк. 6-7.

305 ДАЗО. Ф. 29. Оп. 3. Спр. 36. Арк. 6-7.
} 
interest of some rehabilitation of the bureaucratic apparatus of the Czechoslovak Republic. The exception in this composition of irredent bureaucracy is the financial directorate, whose chief, Czech, has organized a new institution in accordance with the requirements of the republic"306.

Evidence that the pro-Hungarian propaganda in the region intensified at the end of 1920 is the report of the Solotvyno "ulan administration of November 6. In particular, it states: "Political position. In the political context there is now a complete calm in the local county. With the exception of organized workers, the Ruthenian population does not take part in political life. According to secret agents, the Hungarians have recently intensified their campaigning here, especially in the Tiachiv district. Their agitators with the help of print media spread among the people the Hungarian X law on the autonomy of Subcarpathian Rus' and promise to give them state property such as forests and meadows on the basis of the same law, thus trying to attract the sympathies of the Ruthenian people to the Hungarian statehood idea and to the Hungarian state candidates at the coming elections. It is said that this Soim will be competent to decide on the issue of state affiliation of Subcarpathian Rus', and therefore, somehow, it is very important who will be elected to the Soim.

The pro-Hungarian agitation in the Rakhiv district is headed by lawyer Dr. Shtefan, brother of Gustav Shtefan, who was appointed by the Hungarian Ministry in Budapest as governor of the "Rus' Land" and who is now in Poland, leading the agitation for the annexation of Slovakia and Subcarpathian Rus'. His associates include the priest Demianovych, a teacher at the Church School - Chengery, the chief of the Rakhiv forest board - Weiss, and former official of the district government - Julius Hizer, who refused to take the oath for which he was fired. Another base of Magyarons is the management of the state forests, which were hired by the Czechoslovak Republic and are hated by the local people" 307 .

At the end of 1920 the first cases of delivery of a firearm to the territory of the region were recorded. On November 15, 1920 Chief of the Civic Office of Subcarpathian Rus' informed the Czech Republic

306 ДАЗО. Ф. 29. Оп. 3. Спр. 22. Арк. 135-136.

307 ДАЗО. Ф. 29. Оп. 3. Спр. 28. Арк. 102-104. 
representative in Budapest that "a parish priest in Nyzhni Veretski Andor Kompordai, together with his brother Julius Kossey, keep in touch with Hungary and Poland, distribute postcards of Dr. Mykulash Kutkafalvi, use poverty, which rules in the mountainous regions and finally had an agreement with the Polish army to deliver large quantities of weapons and distribute them to the local people to prepare for an armed uprising. After the conspiracy was exposed, priests Kompordai and Julius Kossey managed to flee abroad to Poland, where, according to rumors, they are still staying. His wife and several other civilian and military men were arrested. The wife of the priest Kompordai, as it was identified by the investigation, assisted her husband in all his treasonous affairs and was therefore referred to the Beregovo Prosecutor's Office for treason. The criminal case against the aforementioned person was conducted, but Beregovo prosecutor's office offered a pardon"308.

In June 1921, an official center for irredent propaganda in the territory of Czechoslovakia, Yugoslavia, and Romania was organized at the Ministry of Foreign Affairs of Hungary in Budapest, it was called "Protecting Minorities of the Occupied Territories". The Center was divided into three parts: Slovakia (Felvidek), Romania Transilvania (Erdel) and Yugoslavia (Backa). The Romanian branch of the irredent center, which was located in the Ministry of Foreign Affairs of Hungary, consisted of eight departments for eight Transilvanian counties (districts), each department was divided into three offices, namely: 1) a bureau (cadastre) -1 employee $-\square$ monitored all figures of Hungarian nationality who were capable of active propaganda in the district; 2) a bureau (cultural propaganda) $\square 1$ employee $-\square$ provided propaganda through the press (leaflets, brochures, books, films) and monitored teachers and priests of the district who devoted themselves to irredent activities; 3) a bureau (irredent) was engaged in the registration and sending of its own couriers (numbering 250 people). An important fact is that couriers travel to Romania via the territory of the Czechoslovak Republic, namely through the Kiralyhaza-Halmi" ${ }^{309}$.

308 ДАЗО. Ф. 29. Оп. 3. Спр. 123. Арк. 57-58.

309 ДАЗО. Ф. 29. Оп. 3. Спр. 124. Арк. 114. 
Hungary has often used students and intellectuals to promote its ideas. On June 26, 1921, the Civic Office of Subcarpathian Rus' in Uzhgorod informed all the provincial offices about an attempt to carry out, with the assistance of Hungarian students, a large-scale campaign for the annexation of Transcarpathia to Hungary. In Uzhgorod alone, about thirty students, who lived in their local families under the guise of visiting relatives, arrived. A large number of students came to Mukachevo and Beregovo. The entire campaign is run by one of the leaders of the Hungarian Party of Right Dr. Endre Korlat and editor Tivodar. Lieutenant Colonel on the retirement, Ark Akosh, also took part in this work. Uzhgorod, Mukachevo and Beregovo became centers of this movement. The report said that "three major Hungarian parties are holding meetings with the representative of the "Rus' Agricultural Union", Dr. J. Kaminski, to bring him and the whole party to their side for the Great-Hungarian chauvinistic purposes,... they are working on Kaminski's appointment as a governor. If these negotiations had led to the goal, then all the Hungarian parties and Dr. Kaminski's party would have formed a large joint bloc. The mentioned above students are agitating that Hungary is the center where locals used to go to work and always found it, whereas now they cannot cross the Czechoslovak border. Therefore, the people are suffering misery and violence from the Czechoslovak authorities, so the local population must seek to move Subcarpathian Rus' back to Hungary... Appropriate measures must be taken to counteract possible agitation and its consequences" 310 .

The irredent activity was so intensified that an official of the Ministry of Internal Affairs of Czechoslovakia wrote to the minister on July 31, 1921: "The irredent movement will sooner or later make a serious upheaval in the country" 311 . Similarly was recorded on August 27, 1921, by a representative of the police department of the Civic Office of Subcarpathian Rus': "The reports from various institutions show that here (in Transcarpathia - Aut.) the Hungarian national propaganda is carried out by all forces" ${ }^{312}$. He was convinced that "the mainstay of it is the Hungarian Christian-Social Party,

310 ДАЗО. Ф. 14. Оп. 1. Спр. 55. Арк. 1-3.

311 ДАЗО. Ф. 29. Оп. 3. Спр. 183. Арк. 1-2.

312 ДАЗО. Ф. 29. Оп. 3. Спр. 193. Арк. 36. 
whose activities turn into a true irredent (the proof of this is the celebration of St. Stephen, which had a humiliating character, wearing Hungarian suits, lectures about unhappy Hungary, etc.), the same time the catholic character of this party is totally negative, which is also evident from the fact that in the Christian Social Party there are also progressive people and a significant number of Jews. Its core is Hungarian nobles, civil servants (mostly dismissed) and officers. The main propaganda support of this party are students studying in Hungary, who repeatedly and without passports cross the border and bring from there the leaflets, different rumors"313.

In the early 1920's the first information about A. Brodi's proHungarian activities was recorded. On April 27, 1922, the chief of the police department in Mukachevo reported to the Presidium of the Mukachevo County Department that "editor Brodi is visited by a former financial adviser to the local district administration, Mykhailovych (possibly pseudonym - Aut.), who was once arrested here for organizing Hungarian-Polish legia and was transferred to a divisional court in Uzhgorod. Dr. Mykhailovych is now in Budapest, where he was recently visited by his father-in-law Peruzzi, a restaurateur from Mukachevo" "314. Since this time, Czechoslovak police will follow every step of the future Prime Minister of Subcarpathian Rus'. Czechoslovak police and security also continued to oversee J.Kaminsky, Bako Gabor and other pro-Hungarian politicians of the region ${ }^{315}$. Hungarian irredentists have established contacts with political figures in England and Italy. It was proved that J. Kaminsky set up a close relationship with the English consul in Prague $^{316}$. It is necessary to agree with the opinion of the Presidium of the Mukachevo County Administration that "the victory of Italian fascism awakened the tumultuous Hungarian temperament of the fanatical mass" 317 . Under the influence of events in Italy, "the Hungarian gendarmes continued to threaten that our border would not remain as it is now, and they believe that they will have a service in

313 ДАЗО. Ф. 29. Оп. 3. Спр. 183. Арк. 36.

314 ДАЗО. Ф. 13. Оп. 1. Спр. 654. Арк. 1.

315 ДАЗО. Ф. 29. Оп. 3. Спр. 228. Арк. 20-21.

316 ДАЗО. Ф. 29. Оп. 3. Спр. 228. Арк. 1.

317 ДАЗО. Ф. 29. Оп. 3. Спр. 228. Арк. 26-28. 
the Carpathians this spring. These gendarmes lead such conversations with our border guards. On January 21, 1923 at night reflector from the Hungarian side shone on our side, and on 20 of the same month on our border there was heard a firing machine gun for about an hour on the Hungarian side" 318 .

The evidence of the attack, which is being prepared for one of the county offices of Subcarpathian Rus', "forced the security agencies to conduct enhanced searches, which, however, ended to no avail, as it is not excluded that officers and non-commissioned officers, who were sent to make this attack, failed to do so due to timely taken actions. Now, however, the excitement caused by the events in Hungary and Germany has subsided, however, one can still constantly see the population's partial uncertainty..."319.

In the mid-20's there is an increase in the activity of the Hungarian irredent in Transcarpathia. During this period, they consolidate their forces, unite, form the main irredent centers. On February 9, 1925, the Presidium of the Mukachevo County Administration reported to the Presidium of the Civic Office of Subcarpathian Rus' in Uzhgorod about the election of E. Korlat as a head of the opposition Hungarian forces. "In a secret way," the report said, "it was established that on January 31, 1925, representatives of the executive committee of the union of opposition Hungarian parties in Subcarpathian Rus' met for a secret meeting in Beregovo, at the secretariat of the party of small hosts. The meeting was chaired by Arki from Uzhgorod and the issue of ways to secure a united front of the opposition Hungarian parties was discussed. At the meeting, there were sharp disagreements between individual participants, and a vote was taken as to whether trust to Dr. Korlat should be expressed. With a small number of votes it was voted for such a trust" ${ }^{\prime 320}$.

In the mid 1920's there is an increase in activity of pro-Hungarian forces in Subcarpathian Rus'. Often a variety of methods have been used to achieve their goals, such as leaflets, memoranda, etc. Senior Police Advisor Voglidal informed the Presidium of the Civic Office of Subcarpathian Rus' about the revanchist propaganda of the

318 ДАЗО. Ф. 29. Оп. 3. Спр. 228. Арк. 27.

319 ДАЗО. Ф. 29. Оп. 3. Спр. 212. Арк. 9-10.

320 ДАЗО. Ф. 29. Оп. 3. Спр. 428. Арк. 127. 
Budapest Bank of Roth's firm all over in Slovakia and Transcarpathia. This bank proposed to put dollars, English pounds, Swiss francs and Czech krones for Budapest houses and estates in Hungary at $32 \%$ per annum. It is interesting that on the title page of the project, developed by the bank, issued in May 1925, a number of slogans were printed in Hungarian and French, in particular, "we believe in one god, we believe in one homeland, we believe in eternal and divine law, we believe in the resurrection of Hungary", "without expansion of production it is impossible to re-surround Hungary with the previous radiance of glory, without American capital it is impossible to raise our production", "Hungarian, stay always and everywhere Hungarian", etc. ${ }^{321}$. On the penultimate page of the project, entitled "Expositions in the Occupied Territory of Hungary", there were listed the cities that were once part of it (Uzhgorod, Bratislava, Kosice, Trencin, Beregovo, Mukachevo, Khust, Rakhovo, Timisoara, Zagreb, Fiula, etc., total of 114 cities) ${ }^{322}$.

Transcarpathia was literally flooded with Hungarian agents. Since November 1927, the Presidium of the Mukachevo County Office has reported to the Presidium of the Civic Office of Subcarpathian Rus' about the espionage of priest Karl Barkase in favor of the Horthy's Hungary. "I inform," the head of the Mukachevo county reported, "that the Evangelical Reformed parish priest Karel Barkase from the village of Saloka (Uzhgorod district), together with the priest Shtefan Sabo from the village of Yasenya (Uzhgorod district), and Ladislau Matyash from Ilok in Hungary commited military treason, because in 1923 he sent to Hungary various maps, lists of gendarmes and financial watch stations, their location, strength, weapons, personnel by nationality, as well as information on the location of Czechoslovak military units, their forces in different garrisons. These materials were hidden at Matyash's, who at the time was serving under the border financial guard at the section between Tisosentmarton and Soloka. On June 18, 1923 these materials were again received by the priest Barkase and together with Matiash they were sent to the military commandant's office in Mondok, where they were transferred" ${ }^{\text {"323. }}$

321 ДАЗО. Ф. 29. Оп. 3. Спр. 484. Арк. 20-21.

322 ДАЗО. Ф. 29. Оп. 3. Спр. 484. Арк. 21.

323 ДАЗО. Ф. 2. Оп. 1. Спр. 44. Арк. 78. 
The Czechoslovak security service detained Ladislau Matyash in the village of Kapushany on July 25, 1927, and handed him over to the police in Kosice. The detainee testified against Barkase and Sabov, thereby confirming the testimony of J. Godvan, made on August 26, 1923. This gave reason to arrest Barkase and put him in the investigative prison of Uzhgorod" 324 .

Similar espionage activities of Hungarian agents were recorded in Yasinia and Khust. On November 29, 1927, the newspaper "Czech Word" reported that "police and gendarmerie managed to expose extensive espionage for Hungary in Subcarpathia. Two residents of Yasinia village and one pensioner from Khust were arrested and taken to the Khust district court jail. It was found that the arrested (their names are kept secret) were in contact with Hungarian lawyer Dr. Ekman of Shatoro-Uygel, on the border of Czechoslovakia; they received money and orders to increase agitation among the Hungarian population in Transcarpathia and return of the Hungarian regime" 325

Some pro-Hungarian parties in Transcarpathia have intensified their activities. This is especially concerned with the gas stations. The named party, headed by I. Kurtyak, promised generous fees and banquets to support the gas stations during the election. "That many of the invited and honored to receive letters of the "people's awakeners" did not respond to sly promises," the "Podkarpackie Glasi" newspaper stated, "it is evident from the success of the autonomous union in the elections, so it is likely that the generosity of uncle from Budapest will be limited further, ${ }^{326}$. However, Budapest continued to finance gas stations. This also applies to parties of small farmers. The head of the Mukachevo County informed the Presidium of Subcarpathian Rus' Office: "It is well known that Hungary is spending considerable funds for its political purposes. In particular, during the recent elections to the village councils, this fact was confirmed. The party receives assistance from Hungary, and for this reason it must contact Baron Zsigmond Perenyi in Budapest. Money parcels are allegedly run from Hungary through the Great

\footnotetext{
324 Ibid.

325 ДАЗО. Ф. 29. Оп. 3. Спр. 769. Арк. 26.

326 ДАЗО. Ф. 30. Оп. 4. Спр. 439. Арк. 1.
} 
Sevliush",327. This information was confirmed by the deputy chief of the Mukachevo district administration. "Undoubtedly," the report said, "this party receives systematic assistance from Hungary. In order to do this, the Hungarian small-peasant party must be in contact with Zsigmond Perenyi in Budapest. The mentioned person at one time was a head of Maramoros County, and later Minister of Hungary. Zsigmond Perenyi has got several agents in Velyky Sevliush, in particular, such an agent was a deceased director of the Velyky Sevliush County Hospital, Dr. Koloman Nagy, an active member of the Hungarian Party of Peasant Socialists, former Baron's family doctor. Remittances, apparently, are sent from Hungary through Velyky Sevliush" ${ }^{\prime 28}$.

Under the heading "completely secret" the director of the Uzhgorod police informed on June 16, 1928 the Presidium of political management of Subcarpathian Rus' that in Hungary "all public servants, as well as persons living at the expense of the population, are militarized. They all use the smallest opportunity to attack our country and talk about the capture of Slovakia and Subcarpathian Rus' in the near future" ${ }^{329}$. Even some details were cited in the report: "In state institutions, in some cafes there are maps on which there is no Czechoslovak Republic at all. In cafes, restaurants irredent songs are sung. The rural population, who strongly condemns the Hungarian bourgeois-nationalist demonstrations, has a very different mood, although it must remain silent and is severely persecuted for every word of criticism. Based on the judgments of the local agents, the Hungarian government has many problems with its own population at home, which is very dissatisfied with the social conditions" ${ }^{330}$.

The talks about a close Hungarian invasion continued. On July 27, 1928 the Presidium of the regional board of Subcarpathian Rus' informed the Uzhgorod Regional Gendarmerie Office: "Hungary, in case of a military conflict with Czechoslovakia, hopes very much for the support of the Hungarian population living in Slovakia and Subcarpathian Rus'. It must be properly organized so that Hungary's

${ }^{327}$ ДАЗО. Ф. 29. Оп. 3. Спр. 796. Арк. 46.

328 ДАЗО. Ф. 29. Оп. З. Спр. 796. Арк. 47.

329 ДАЗО. Ф. 29. Оп. 3. Спр. 781. Арк. 147.

330 ДАЗО. Ф. 29. Оп. 3. Спр. 781. Арк. 147. 
invasion of Slovakia would be as successful as possible. Hungarian military circles also envisage that in case of a military conflict the Hungarian population will start protests that will not allow Czechoslovakia to make defensive preparations. Such an organization of the Hungarian population is being held, probably, in Transylvania... Who conducts the organizational work among the Hungarian population in Slovakia and Subcarpathian Rus' is not known, however, according to secret information, this is primarily done by Hungarian political parties, in particular, the Hungarian Peasant Socialist Party... This party is in constant contact with the government's Hungarian circles, who constantly assure it that the current situation will not last long and that Hungary will soon try to occupy Slovakia. The Hungarian Peasant Socialist Party has launched extraordinary organizational activities, its activists are constantly traveling around villages, strengthening and organizing new organizations, and the leaders of this party, in particular, the parliamentarists Sulle and Dr. Korlat, Senator Egri (these are more likely supporters of the Peasant Socialist Party) often go to Hungary" ${ }^{331}$.

On March 21, 1929 the chief of police in Uzhgorod informed the Presidium of the regional administration of Subcarpathian Rus' about the connections of Hungarian spy $\mathrm{T}$. Hulovich with the Hungarian nationalist parties in Transcarpathia" ${ }^{332}$. On August 18, a priest from the village of Chepa, Eugene Biki, was arrested for the pro-Hungarian activity $^{333}$. Supervision of the agents of Z. Perenyi continued ${ }^{334}$. On May 11, 1929, witnessing in the Irshava District Court, I. Iltio stated: "I can confirm as a witness that the party of deputy Kurtyak (AZS Aut.) is supported or was supported by Hungary... The party apparatus costs about half a million crowns. In Subcarpathian Rus, it is common knowledge that members do not pay membership fees. I personally know that a secretary of Kurtyak's party, named Demko, never wanted to speak against the Hungarians. This party published

331 ДАЗО. Ф. 29. Оп. 3. Спр. 781. Арк. 97.

332 ДАЗО. Ф. 9. Оп. 1. Спр. 60. Арк. 34.

333 ДАЗО. Ф. 29. ОП. 3. Спр. 796. Арк. 30.

334 ДАЗО. Ф. 9. Оп. 1. Спр. 60. Арк. 39. 
Hungarian books, and did not want to do anything for the Rus' culture" 335 .

Hungary was seriously preparing to invade Slovakia and Subcarpathian Rus'. This was confirmed by the police chief in Kosice Eis Chenek on December 11, 1929, in the report to the directorate of the Presidium of the regional administration in Bratislava. The above report referred to one of the meetings of the Hungarian General Staff. "According to this information," E. Chenek reported, "some members of the Hungarian government seemed to be surprised that the government was not informed of the meeting of the General Staff Council, especially since issues related to its competence were being resolved. The council did not even announce that its members were discussing it. With this secret, the Hungarian government is feeling insulted, and most members of the government have submitted an interpellation to Minister Gembesh. And he would sort of answer briefly that they talked about military issues that cannot be discussed openly"336. According to Czechoslovak intelligence, "there will be changes in important positions in the Hungarian army after some time, and it is said that Commander-in-Chief Janki Kotschard will resign and a cavalry general Baron Tan will replace him. General Gukfi has been appointed commander of a military organization in Slovakia and Subcarpathian Rus', who previously had been attached to the VI branch of the Ministry of Defense. He, as commander-inchief in Slovakia and in Subcarpathian Rus', will take lead over 5 commanders who reside in the Czechoslovak Republic and who, after their appointment, are expected to receive regular payment" ${ }^{\text {"337. }}$.

On March 11, 1930 the Czechoslovak Ministry of National Defense reported to the Ministry of Internal Affairs that "Hungarian propaganda had succeeded in establishing a press center in Prague, which is part of the Hungarian irredentist and espionage service in our territory" 338 . The irredentist newspapers have been united around the "Pragai Magyar Hirlap". Hungarian agents often have used various sports clubs for their purposes. On March 21, 1930 Governor

335 ДАЗО. Ф. 30. Оп. 4. Спр. 416. Арк. 2.

336 ДАЗО. Ф. 117. Оп. 1. Спр. 136. Арк. 1.

337 ДАЗО. Ф. 117. Оп. 1. Спр. 136. Арк. 1.

338 ДАЗО. Ф. 117. Оп. 1. Спр. 161. Арк. 1. 
Rozsipal informed the district administration about the connections of the Beregovo sports club with the leaders of Horthy's Hungary ${ }^{339}$. The district commander in Svalyava convinced the Presidium of the regional administration in Uzhgorod that the local "Roman Catholic church today, even more than before, under the influence of the proHungarian elements intensified its activity" ${ }^{140}$. A Budapest-made map "Hungary before and after the Trianon Peace" was distributed on the territory of the region" ${ }^{341}$. On January 13, 1934 Gembesh, accompanied by senior ministry officials, arrived in Chatorougeil, where he delivered a speech to the members of the county administration, stating that in its foreign policy Hungary had moved so far forward and so strongly that it came to the required revision of the borders already for 7,5\%,342.

On April 16, 1933, an article "Plan of Hungarian Revision" was published on the pages of the Hungarian newspaper "Kish Uysag". It said, in particular: "A big part of the Upper Territory with half a million population would be reached again. First of all, Rye Island, so as the territory of Ruthenians, where a council of delegates appointed a plebiscite. A number of Hungarian towns would come back to us again: for example Uzhgorod. From the territories occupied by Romania, more than 1,000,000 Hungarians would be annexed to Hungary. Verazdin, Satu Mare and Arad would come into Hungary. Hungary would take Backa, which is occupied by Serbia, as well as a large part of Banat, primarily Subotica, South Baranya and Mesimorte. Western Hungary would have fallen to us completely. At the meetings, Chancellor Dolfluss and the leader of the German people discussed the issue of Western Hungary, which is annexed to Austria. This detached part of the empire is not disputed by either the German National Socialists or the Austrians" ${ }^{\text {"343 }}$. A great number of books were devoted to this subject in Hungary, they were brought to Transcarpathia by mass circulation. This was repeatedly reported to

\footnotetext{
339 ДАЗО. Ф. 117. Оп. 1. Спр. 136. Арк. 1-2.

340 ДАЗО. Ф. 2. Оп. 2. Спр. 359. Арк. 11.

${ }^{341}$ ДАЗО. Ф. 2. Оп. 2. Спр. 326. Арк. 34.

342 ДАЗО. Ф. 2. Оп. 2. Спр. 359. Арк. 29.

343 ДАЗО. Ф. 2. Оп. 2. Спр. 284. Арк. 128-129.
} 
the Presidium of the Regional Office by the Chief of Police Flek ${ }^{344}$. Hungary continued to spread rumors of a close invasion. On May 19, 1935 the Ministry of the Interior of Czechoslovakia issued an order to strengthen the protection of the Czechoslovak-Hungarian border due to the possible invasion of the Hungarian armed groups. In particular, it stated: "The activities of individual gendarmerie units in the protection of the Czechoslovak-Hungarian state border from the possible penetration of armed groups into our territory requires that the order concerning the area in Rozhniava also applies to the gendarmerie units in Kosice and Trebisov. The full implementation of this order must be fulfilled by two gendarme commands with the prior agreement of the regional authorities"345.

On July 7, 1936 the head of the Gendarmerie station in the village of Chaslivtsi, ensign Kafourek reported to the local gendarmerie command in Uzhgorod about the spread by the Hungarian agents among the population of the rumors about the occupation of Transcarpathia by Hungarian and Italian troops in the near future ${ }^{346}$. A similar situation in the Hungarian border villages was reported by the head of the district department of Uluwacek: "Rumors are circulating in the Hungarian border line that there will be a war during which Hungary will unite with Germany and Austria and that the occupied territory will once again depart to Hungary. The secret agent of the gendarme point in Petrov reported that in Debrecen he allegedly saw German officers who were to take part in the Hungarian maneuvers"347.

In the late 1930s, the anti-Czechoslovak and anti-Ukrainian activities of the pro-Hungarian "fifth column" in Transcarpathia culminated. Modern researchers rightly believe that in 1938-1939 the overwhelming majority of the Hungarian population, "which have been waiting for the inclusion of the region in Hungary from day to day", were hostile to the Ukrainian government ${ }^{348}$. A. Voloshyn and

\footnotetext{
344 ДАЗО. Ф. 2. Оп. 2. Спр. 450. Арк. 62.

345 ДАЗО. Ф. 2. Оп. 2. Спр. 418. Арк. 183.

346 ДАЗО. Ф. 2. Оп. 2. Спр. 301. Арк. 50.

347 ДАЗО. Ф. 2. Оп. 2. Спр. 301. Арк. 19.

348 Болдижар М. Закарпаття між двома світовими війнами. Ужгород, 1993.

C. 125 .
} 
his close associates understood this. Describing the events of October 30, 1938, when anti-Ukrainian demonstrations took place in a number of cities in Transcarpathia, V. Grendzha-Donsky noted: "From the morning we have seen great tension and animosity towards us... In front of the People's House there was a hostile crowd, as the wasps: "Get away with the Ukrainians! Long live Brodi! Long live Horthy!...349 . And there were many such cases.

Anti-Ukrainian propaganda did not stop throughout the short-lived existence of Carpathian Ukraine. Newsletter of the Press Service of Carpathian Ukraine reported that "The Motherland, without sparing money, human sacrifices, works tirelessly to reach its 20-year goals" 350 . A. Voloshyn asked his government officials to be ready to repel hostile propaganda: "It is reasonable to believe that Hungarian propaganda will want in a short time all the constructions for presenting the recently taken territories to the world as a result of its work. If you are to prepare the appropriate material against this propaganda right now, I ask you... to send me all the material you have that would speak about it? How did the now-abandoned territory look like in 1919 (including the cities of Uzhgorod, Mukachevo and Beregovo), what investments were made in that territory until 1938 and at what cost. To clarify the matter, please, also send me the photographic material you have" 351 . Thus, the government of A. Voloshyn was not surprised by a sharp increase of anti-Ukrainian propaganda and agitation in the region.

Throughout this period, leaflets were distributed by the proHungarian elements in the cities and villages of Carpathian Ukraine, and there were pronounced slogans "Get Out with the Czechs!" and 'Beat the Czechs!", which sought to sharpen relations between Carpathian and Czechoslovak governments. A. Voloshyn demanded that the Ministry of Internal Affairs of Carpathian Ukraine "all such anti-state and anti-national agitation should eliminate at the root and that the initiators of the anti-Czech agitation should be restrained and actions against them should be vigorous" ${ }^{352}$.

\footnotetext{
${ }^{349}$ Гренджа-Донський В. Щоденник. Твори. Т. VIII. Вашингтон, 1987. С. 108.

350 ДАЗО. Ф. 17. Оп. 1. Спр. 9. Арк. 2.

351 ДАЗО. Ф. 3. Оп. 1. Спр. 156. Арк. 1.

352 ДАЗО. Ф. 3. Оп. 3. Спр. 65. Арк. 62-64.
} 
The leaflet propaganda intensified in the run-up to the plebiscite, which was demanded by the Hungarian government. The so-called "Committee of Independence of the Ruthenians" called on the population: "Brothers! - we do not need Czech and Ukrainian nobility, but Magyar lowland... We lived with the Czechs only 20 years, but with the Magyars we lived for 1000 years together. Do you want this old happy world be back? It's up to you! Vote for a common homeland of Russians and Magyars!" ${ }^{\prime 353}$. The same "Committee" convinced the Transcarpathians of the need for coexistence with Hungary, because only it "will give us freedom, earnings and a better future" ${ }^{354}$. Leaflet "The people of CarpathoRuthenians! The Carpatho-Ruthenian brothers!" called for the protection of A. Brodi, who "for our truth bears persecution... He suffers for the fact that he wanted, so as we wanted, the happiness of the Carpatho-Ruthenian people, who wanted the connection of Subcarpathian Rus' with Hungary" 355 . Leaflet "Sisters and Brothers!" was issued immediately after the elections to the Soim of Carpathian Ukraine. Its authors called for a joint struggle of the Ruthenians and the Hungarians against "Voloshyn, Revai and the Ukrainian nobility", to meet "our liberators - Magyar Honveds" 356 . The same slogans were put forward at the public meeting of Fentsyk's supporters in Svalyava ${ }^{357}$. A Czech-language leaflet called "Listen to This and Remember It!" has openly called for terror. It ended with the words: "Our patience is over!"358. Czechoslovak Security Service closely monitored anti-Ukrainian and anti-Czech political organizations ${ }^{359}$.

There were various ways of delivering leaflets to designated areas. Before the Vienna Arbitration on November 2, 1938, they tried to distribute them in the towns and villages where the Hungarians lived. "Until now (May 2, 1938) two newsletters were circulated about the distribution of leaflets," said the chief of the police department in

53 ДАЗО. Ф. 3. Оп. 3. Спр. 170. Арк. 5.

354 ДАЗО. Ф. 3. Оп. 1. Спр. 24. Арк. 3.

355 ДАЗО. Ф. 4c/18. Оп. 1. Спр. 80. Арк. 4.

356 ДАЗО. Ф. 3. Оп. 2. Спр. 14. Арк. 6.

357 ДАЗО. Ф. 4c/18. Оп. 1. Спр. 24. Арк. 1-4.

358 ДАЗО. Ф. 3. Оп. 1. Спр. 24. Арк. 3.

359 Archiv Ministerstva Zagranicnich Veci, Praha. karton 642. 
Uzhgorod to the Presidium of the district administration, "from Sevlyush and from Beregovo, the cities where the Hungarian population is most residing... In Sevlyush district circulars of the deputy Korlat (the Hungarian parliamentarist, who openly declared a future annexation of Transcarpathia - Aut.) were secretly handed over to the Jews. But the Jews, with few exceptions, refused to take circulars. The campaign was interrupted by communists who led a strong agitation against the Hungarian opposition among the population" 360 .

The leaflets were forwarded to their agents in Transcarpathia, and were reprinted and distributed here. Czechoslovakian police found that one of the activists of the Hungarian National Party in Beregovo, Bodak, "printed the mentioned leaflets in the Merkur's typography, which is in the same room with the secretariat of the Hungarian National Party, made a list of all Hungarians and Jews, and ordered his servant Antonin Maroek to spread them in Beregovo from house to house. The leaflets were enclosed in a blue newspaper folder" ${ }^{361}$. Czechoslovak police have proved that "the person of the extreme Hungarian way of thinking was signing by his full name, while persons working in public institutions and persons who were hesitating were signing with different signs, only to make it clear in the list that they received the leaflets" ${ }^{\text {} 362}$. Thus, Hungarian agents, distributing leaflets, relied primarily on the Hungarian-speaking population.

Often postcards were thrown into the territory of the region from the aircraft. "The leaflets in Russian and Ukrainian," the head of the Vyshkovo gendarme point reported to the chief of the Khust district, "contain appeals to the local population to speak out against citizens of Czech nationality and to pay no taxes. As it was found out, the leaflets were dropped on October 17, 1938 after 11 a.m. from a foreign plane flying along the state border from Tiachevo in the direction of Khust. The thrown leaflets fell into the free territory and inaccessible places of the local area and in most cases fell into the hands of citizens of Ruthenian nationality living separately along the

360 ДАЗО. Ф. 2. Оп. 1. Спр. 315. Арк. 28.

361 ДАЗО. Ф. 2. Оп. 1. Спр. 315. Арк. 29.

362 ДАЗО. Ф. 2. Оп. 1. Спр. 315. Арк. 30. 
Czechoslovak-Romanian border. The population does not react to the content of the leaflets" ${ }^{363}$.

Thus, Czechoslovak police closely followed the distribution of the Hungarian leaflets and often confiscated them. Such fate awaited Polish leaflets. The chief of Dubrynychi gendarme point, Malek, reported to the head of the security service of Subcarpathian Rus' that he had confiscated Polish postcards under the titles "Brothers", "Dear Ruthenians Brothers", "Carpathorussian Brothers"364" The Czechoslovak police was also taking Polish agents in the field of its view. "Yaroslav Boyko from Berezhany region," "Nova Svoboda" reported, "is a dangerous person, and this way we warn Ukrainian citizenship in Galicia about him. Some illustrations of his activity: in Uzhgorod about 28.10. this year (1938 - Aut.) he asked for social work as a political prisoner, who was taken to Poznan during the investigation, from where he fled through Katowice to Germany, from Czechs and Slovakia to Carpathian Ukraine. A few days later he appeared in Mukachevo, where he introduced himself as a banished Ukrainian nationalist from the camp in the Carpathian Mountains, which numbered there at about 5000 people awaiting orders to cross the border. Taking advantage of the confusion encountered during the evacuation of Mukachevo and Uzhgorod, he fled through Yasinia to Lviv, where he turns around the Ukrainian editorial office and searches for the victims, offering them his help to transfer them to Carpathian Ukraine with the highest security"365.

The State Prosecutor's Office in Veliky Bereznyi reported: on December 22, 1938 "there was detained by the gendarme point in the village Huklyve Vasyl Gubanii, who ... publicly campaigned against the authorities of Carpathian Ukraine and its prime minister, at the same time he... was spreading the journal "Dnevnyk"366. The State Prosecutor's Office opened a criminal case against those who campaigned against A. Voloshyn's government and for joining the village Pidhoryany to Hungary ${ }^{367}$. On November 30, 1938 Yurko

\footnotetext{
363 ДАЗО. Ф. 17. Оп. 1. Спр. 327. Арк. 14

364 ДАЗО. Ф. 18. ОП. 1. Спр. 80. Арк. 3.

365 Нова свобода. 1938. 6 грудня.

366 ДАЗО. Ф. 17. Оп. 2. Спр. 336. Арк. 1.

367 ДАЗО. Ф. 3. Оп. 2. Спр. 12. Арк. 2.
} 
Hordubei convinced residents of the village Chornyi Potik that "without Uzhgorod and Mukachevo we cannot live" and that only A. Voloshyn is to blame for this ${ }^{368}$. Regional court in Velykyi Bereznyi, on December 8, 1938 sentenced Y. Kleisner and Y. Pashkulyak, "charged by the state prosecutor's office for the crime of conspiracy against the republic under $\S 2$ of the law on protection of the republic. On November 4, 1938, both of them were sent by a well-known Fentsyk supporter, Krainiak, from Radwanka to our homeland to collect signatures in our villages for the accession of the whole Carpathian Ukraine to Hungary... He gave them 12 blank forms with the inscription: "Berni government in..." and handed them a list of communities laid out on the Uzhgorod-Uzhok line. They also received $200 \mathrm{kc}$ for the road and they had to go through all the villages on the list, summon the peasants, and agitate to join Hungary. With these instructions, they came to Uzhok and then walked to Volosyanka, collected signatures, but now they were arrested by the gendarmes... Accused before the gendarmerie and today before the Senate, they completely confessed and each of them got 2 years in prison for that" 369 .

Often priests have campaigned in favor of Hungary. Apostolic Administrator of Carpathian Ukraine D. Njaradi informed the departmentof press and propaganda that "Fr. Silvai Nestor constantly propagates among peasants on the basis of radio announcements from Budapest" ${ }^{\text {"370 }}$. On October 29, 1938 priest from Pistryalov Ivan Josyf "proclaimed that the sweet man Brodi had been thrown out of the ministerial presidency, and Voloshyn replaced him. Voloshyn is a bandit, a thief, he will sell us. If it were Sunday tomorrow, I would go to Uzhgorod myself and kill him"371. Uzhok's priest Zoltan Sholtes was detained for the pro-Hungarian agitation ${ }^{372}$. On December 28, a parson from Patskaniovo, Ivan Min' was detained "for the crime of

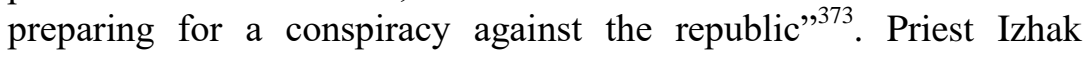

368 ДАЗО. Ф. 3. Оп. 3. Спр. 83. Арк. 6.

369 Нова свобода. 1938. 13 грудня.

${ }^{370}$ ДАЗО. Ф. 3. Оп. 3. Спр. 73. Арк. 30.

371 ДАЗО. Ф. 3. Оп. 3. Спр. 83. Арк. 8.

372 ДАЗО. Ф. 3. Оп. 3. Спр. 170. Арк. 5.

373 ДАЗО. Ф. 4c/18. Оп. 1. Спр. 74. Арк. 1. 
Emerik during the church service urged people to join Tiachevo to Hungary $^{374}$. And there are many such examples. On December 24, 1938 the district commander in Perechyn proposed to A. Voloshyn "...that priests close to the Magyars would be relocated to the third district, so that they come among new people, whom they don't know, and among whom they would not dare to agitate...”375.

The State Prosecutor's Office in Velykyi Bereznyi opened a criminal case against individual citizens who were accused of insulting A. Voloshyn and his government. Driver Filak called the government "the Ukrainian gang"376, and Elizabeth Groskopf on December 24, 1938 declared that "Voloshyn is stupid and all power is stupid" ${ }^{\text {377 }}$. Something like that was said by Samuel Schwimmer, but A. Voloshyn stated that he "did not want further movement in the case ${ }^{\$ 378}$. The Prime Minister put himself above various gossip and intrigues, which almost never stopped in the company of his enemies. However, no matter what A. Voloshyn did in such situations, they undoubtedly gave rise to uncertainty in some segments of the population, undermined the authority of the power. In response to this, the press and propaganda service conducted its counterpropaganda. For this reason, leaflets appeared, which praised A. Voloshyn and his activities ${ }^{379}$. It should be noted that the Czechoslovak security service also collected compromising materials on A. Voloshyn, as before him on A. Brodi ${ }^{380}$.

Pro-Hungarian elements often used methods of threatening and intimidation of local Ukrainian leaders. V. Grendzha-Donsky wrote that the chairman of Volove district council J. Dudykevych "very often receives letters with threats "Tomorrow evening you will die!" - signature: "Black Hand" (Hungarian). The provoked poor almost did not attack him with the axes"381. The press service of Carpathian Ukraine reported that on October 31, 1938, Bodak, "who

\footnotetext{
374 ДАЗО. Ф. 3. Оп. 3. Спр. 73. Арк. 31.

375 ДАЗО. Ф. 3. Оп. 3. Спр. 73. Арк. 1-2.

376 ДАЗО. Ф. 3. ОП. 3. Спр. 45. Арк. 1.

377 ДАЗО. Ф. 3. Оп. 3. Спр. 170. Арк. 1.

378 ДАЗО. Ф. 3. ОП. 3. Спр. 83. Арк. 2.

379 ДАЗО. Ф. 3. Оп. 4. Спр. 12. Арк. 1-2; Оп. 3. Спр. 86. Арк. 6.

380 Archiv Ministerstva Zagranicnich Veci, Praha. karton 655.

${ }^{381}$ Гренджа-Донський В. Щоденник. Твори. T.VIII. Вашингтон, 1987. С. 35.
} 
had long campaigned for Hungary and was a member of the Fentsyk Party, knocked out windows at Ryhan's... The mentioned one was wounded in the head by an ax by Ryhan" ${ }^{\text {"382 }}$. On November 1, 1938 Ivan Opalenyk "was thrown out of the hotel... outside in Perechyn and smashed his head, and that was for the Hungarian agitation"383. Similar facts are recorded in the documents of the Prague archives ${ }^{384}$.

On January 1, 1939 S. Fentsyk visited Hungarian Prime Minister B. Imredy. He was accompanied on a trip to Budapest by proHungarian attorneys, doctors, judges, teachers and representatives of youth organizations. In S. Fentsyk's deep conviction, "they represent $90 \%$ of the interests and desires of the people, and $100 \%$ stand for the policy pursued by B. Imredy. The Transcarpathian people not only pay attention to, but also proclaim the idea, which is preached by Imredi" ${ }^{385}$. The Hungarian Prime Minister expressed hope that the Hungarian flag would soon be raised over Uzhok.

Radio-propaganda was systematically and purposefully conducted from the Hungarian and Polish territories. It was conducted in several directions: first, there were all sorts of stories about Carpathian Ukraine that could not be believed; secondly, Hungary, as if sympathizing to the population of the country, "took under protection" Carpathian Ukraine. Hungarian radio spread falsifications about various uprisings and riots against A. Voloshyn's government. So, in particular, it was about the revolts in Khust for the annexation of the city to Hungary. A number of radio programs have been devoted to the fantastic rise in food prices. It should be noted that such a phenomenon occurred, but the price of bread never reached $20 \mathrm{kc}$, as reported by Hungarian radio.

Even more falsified and even senseless sensations were broadcast by Polish radio. Here are some of them: On November 25, 1938 an army in Khust rebelled against the power of A. Voloshyn, occupied the Khust castle and bombes Prague from there; on November 16, 1938 an epidemic of Asian plague broke out in Khust. Doctors escaped, and the population is dying. Everyone who leaves the city is

382 ДАЗО. Ф. 3. Оп. 1. Спр. 50. Арк. 2.

383 ДАЗО. Ф. 3. Оп. 1. Спр. 50. Арк. 3.

384 Archiv Ministerstva Zagranicnich Veci, Praha. Karton 606, 620.

${ }^{385}$ Orszagos Leveltar. K-429, tetel 28-30, 202 óld. 
mercilessly shot. The corpses of thousands of people lie on the street; on November 27, 1938 there's a terrible famine in Subcarpathian Rus'. No one has seen bread for a long time. Many cases of cannibalism have been reported; November 28, 1938. Tonight the earthquake destroyed Rakhiv. The whole neighborhood is flooded with water. None of the population escaped ${ }^{386}$.

The Hungarian secret service closely followed the developments in Carpathian Ukraine. According to Koffa's teletype message, dated January 14, 1939, more than 740 reports from various Hungarian agents were received from Carpathian Ukraine ${ }^{387}$. Koffa (Hungarian agent's nickname - Aut.) reported that "180 Ukrainian terrorists (Galicians - Aut.) appeared in the vicinity of the settlement of Gordycho, and 160 in the Kosyno neighborhood"388. Budapest constantly received reports from the Hungarian agents about mobilization in the armed forces of Czechoslovakia. During January 13-29, 1939 an agent called "Koffa" conveyed by teletype that "all Romanians, who had been sent to the reserve in 1936-1937, were returned to military units. Many of them are Hungarians. All those who received the conscription notes were asked to appear on January 15,1939 , at their military points at six in the morning. The location of the military points is not known. It is known that most of these recruits are concentrated in the Satu-Mare district"389. Agent "Kuzma" reported that "two soldiers with full ammunition went to their place of residence. In the Czech territory, almost all adults received summonses for immediate appearance in the barracks where they had previously serverd a military service. After five days, they must be moved to other placements" ${ }^{, 390}$. Often, Hungarian agents were even aware of such little things as the number of recruits, the level of food supply, and so on. The aforementioned agent reported to his superiors that there were only 60 people left in the Bratislava prison,

\footnotetext{
386 Вегеш М.М., Міщанин В.В. Проугорська “п’ята колона” у Карпатській Україні (1938-1939 рр.). Молодь - Україні (Наукові записки молодих вчених Ужгородського державного університету). Т. 5-6. До 50-ліття Ужгородського державного університету. Ужгород, 1995. С. 185.

${ }^{387}$ Hadtorteneti Leveltar. Koffa 29, 144/1232, eln.2, vkf. ko.1938.

${ }^{388}$ Hadtorteneti Leveltar. Koffa 29, 144/1232, eln.2, vkf. ko.1938.

${ }^{389}$ Hadtorteneti Leveltar. Koffa 29, 144/1232, eln.2, vkf. ko.1938.

${ }^{390}$ Hadtorteneti Leveltar. Koffa 29, 144/1232, eln.2, vkf. ko.1938.
} 
guarded by soldiers of the 39th Infantry Regiment. All the others (more than 200 people) were released and sent to military units ${ }^{391}$.

Among the tasks set to the Hungarian agents was the collection of compromising materials on the "unreliable" politicians, scholars and teachers of the region. Thus, Agent "G" reported that the physician M. Rizdorfer had a map of Great Ukraine, which "in addition to Ukrainian lands in Poland and in the Soviet Union also includes the territory of Northeast Hungary until Debrecen"392. The Horthy's supporters were aware that "priest V. Lar in the Vynohradovo Seminary gave weapons to girls for the fight against the Hungarians" 393 . Among the unreliable there were the names of Y. Perevuznyk, M. Dolynai and others who, much to the chagrin of Hungarian agents, left Carpathian Ukraine after the occupation of the region by the Hungarians ${ }^{394}$. Drawing teacher J. Bokshai, though he remained in the occupied territory, however, "required Ukrainian citizenship"395.

Following the patriotical transcarpathians continued after the occupation of the region by the Hungarian troops. An unknown Hungarian agent reported that "when Hungarian troops entered Velykyi Bereznyi, teacher Pataki refused to hang the Hungarian flag at school" 396 , and "Greek Catholic priest Bachynsky did not want to perform a national anthem of Hungary during a sermon in the church"397. In Rakhiv, "the priest Voloshyn did a great deal of harm to Hungary" 398 . Teacher Ivancho "constantly ridiculed the Hungarian history while teaching his academic subject" 399 , and the Perechyn school inspector Yu. Petenko "opposed the Magyarization of the schools" $" 400$.

\footnotetext{
${ }^{391}$ Hadtorteneti Leveltar. Koffa 29, 144/1232, eln.2, vkf. ko.1938.

${ }^{392}$ Hadtorteneti Leveltar. 29218/29, eln.2, vkf. ko. 1939, 525 óld.

${ }^{393}$ Hadtorteneti Leveltar. Koffa 2921116/4, eln.2, vkf. ko. 1939.

${ }^{394}$ Hadtorteneti Leveltar. Koffa 2921116/4, eln.2, vkf. ko. 1939.

${ }^{395}$ Hadtorteneti Leveltar. Koffa 2921116/4, eln.2, vkf. ko. 1939.

${ }^{396}$ Hadtorteneti Leveltar. Koffa 2921116/4, eln.2, vkf. ko. 1939.

${ }^{397}$ Hadtorteneti Leveltar. Koffa 2921116/4, eln.2, vkf. ko. 1939.

${ }^{398}$ Hadtorteneti Leveltar. Koffa 2921116/4, eln.2, vkf. ko. 1939.

${ }^{399}$ Hadtorteneti Leveltar. Koffa 2921116/4, eln.2, vkf. ko. 1939.

${ }^{400}$ Hadtorteneti Leveltar. Koffa 2921116/4, eln.2, vkf. ko. 1939.
} 
Thus, along with the numerous terrorist sabotages, internal calm in the region was disrupted by anti-Ukrainian and anti-Czech propaganda, calls for the overthrow of legitimate power. The materials show that in the middle of Carpathian Ukraine A. Voloshyn's government had a serious opposition in the face of pro-Hungarian elements, which he could not but deal with. All these factors acted at the same time and constantly, which made the internal political situation of Carpathian Ukraine unstable and explosive. They hastened the establishment of an authoritarian regime in the land, which treated democratic process as an obstacle. At a meeting of the Ukrainian Central People's Republic, on December 30, 1938, one of the prominent political figures of the region, M. Brashchayko, frankly stated: "The democratic principle is harmful to us"

A. Voloshyn issued several orders for the closure of some editions, which dissatisfied the new government. Such fate befell the journals "Rusyn", "Karpatskyi Holos", "Ruskyi Holos" "402. A. Voloshyn's government has informed the Svaliava district authorities that an order has been issued to immediately close the "Tysa" magazine, which "threatens by its content to the public order and security" $" 03$. The reason for this decision was only two articles published in this journal: "Bread and work, not flying" and "Uzhgorod-Mukacheve",404. The editor-in-chief of the magazine, I. Kovach, and the editor B. Scytovsky convinced their readers that "the new republic and the new Subcarpathian Rus' will not provide them with quiet life, with Rus' culture and with daily piece of bread that they lived until now" ${ }^{\prime 405}$. Often the Transcarpathians themselves demanded the closure of Russophile newspapers. M. Mandryk from Sevliush informed the department of press and propaganda that "every article of the "Dnevnyk" newspaper in a nasty and vile way attacks everything Ukrainian... It is necessary to stop a magazine" $" 406$. It was forbidden to distribute newspapers "Kish Uyshag", "Peshti

\footnotetext{
401 ДАЗО. Ф. 1148. Оп. 1. Спр. 1. Арк. 1.

402 ДАЗО. Ф. 3. Оп. 3. Спр. 48. Арк. 16.

403 ДАЗО. Ф. 3. ОП. 3. Спр. 48. Арк. 1.

404 ДАЗО. Ф. 4c/18. Оп. 1. Спр. 8. Арк. 1.

405 ДАЗО. Ф. 4c/18. Оп. 1. Спр. 80. Арк. 4.

406 ДАЗО. Ф. 3. Оп. 3. Спр. 75. Арк. 4.
} 
Hirlop" and "Eshti Ushag" on the territory of the region" ${ }^{407}$. A. Voloshyn informed S. Sabol that the "Calendar" he publishes will only be printed "when the photographs on pages 39/40 and 45/46 are eliminated" 408 . The above facts indicate the introduction of strict censorship of newspapers and magazines published in Carpathian Ukraine. The vast majority were closed. This also applies to the numerous "Duchnovych Societies". In particular, on November 30, 1938, such "Society" was closed in the village Vyshkovo ${ }^{409}$.

On November 20, 1938 in accordance with the order of A. Voloshyn, a concentration camp Dumen was established near Rakhiv and started operating in Carpathian Ukraine. "Deserters and fugitives from abroad" and "political culprits from our region..."

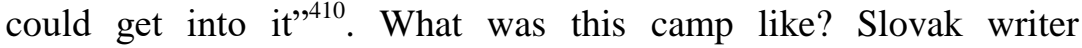
F. Ivancho, who has been in the camp since the second half of December 1938, wrote that "Dumen can be called a concentration camp only conditionally... In the Dumen camp there was a lack of the basic things, without which the real concentration camps cannot exist: double barbed wire fence around the camp square, prohibition area around the camp - zone; at the corners of the camp are the watchtowers with armed guards; dish - according to the percentage of the fulfilled daily norm; working day - 12 hours at any time of the year" ${ }^{\prime 11}$. Undoubtedly, acts such as the closure of print bodies and individual Russophile societies, the formation of a concentration camp, the arrests of unreliable persons (who were, in fact, Hungarian agents) were undemocratic. They testified to the existence of an authoritarian state. However, taking into account a number of factors (difficult international environment, diversions of Hungarian and Polish terrorists, active and purposeful anti-Ukrainian propaganda in the land led by the pro-Hungarian "fifth column", calls for the overthrow of the legitimate government), the government of Carpathian Ukraine, being interested in safeguarding peace in the

407 ДАЗО. Ф. 3. Оп. 2. Спр. 14. Арк. 17.

408 ДАЗО. Ф. 3. Оп. 2. Спр. 65. Арк. 26.

409 ДАЗО. Ф. 17. Оп. 2. Спр. 320. Арк. 1.

410 ДАЗО. Ф. 3. Оп. 1. Спр. 16. Арк. 3.

411 Карпатська Січ. Матеріали наукової конференції. Ужгород, 1996. 
state and in order to create normal conditions in the land, decided to go for a certain curtailment of democracy and to consolidate all the patriotic forces of Transcarpathia.

Consequently, the anti-Ukrainian and anti-Czech activities of the Hungarian irredent, which did not cease throughout the interwar period, culminated in the late 1930s. Transcarpathia was flooded with Hungarian agents collecting signatures for the annexation of the region to Hungary, distributing leaflets of anti-Ukrainian content, and reporting on the activities of some political figures in Carpathian Ukraine. Hungarian and Polish radio propaganda was systematic and targeted. The Czechoslovak and Ukrainian governments have made every effort to resist hostile propaganda, but they could not ignore it. The activities of the pro-Hungarian "fifth column" accelerated the establishment of an authoritarian regime in the region, whose attributes were the closure of certain printing bodies and Russophile societies, the opening of a concentration camp to isolate internal and external enemies of Carpathian Ukraine. Such a move by A. Voloshyn's government should be considered as justified because it was necessitated by the creation of optimal conditions for the functioning of the young state. 